https://doi.org/10.52058/2786-5274-2021-2(2)-116-124

Федоренко Владислав Леонідович доктор юридичних наук, професор, директор, Науково-дослідний центр судової експертизи з питань інтелектуальної власності Міністерства юстиції України, Заслужений юрист України, бульвар Л. Українки, 26, офіс 501, м. Київ, 01133, тел.: (044) 221-12-45, e-mail: fedorenko900@gmail.com, https://orcid.org/ 0000-0001-5902-1226

Жукова Ірина Віталіївна кандидат наук з державного управління, доцент, проректор з наукової роботи, Приватний вищий навчальний заклад Університет нових технологій, вул. Метробудівська, 5А, м. Київ, 03067, тел.: (063) 951-78-55, e-mail: irina_pravo@ukr.net, https://orcid.org/0000-0003-4927-0610

Щурба Мікеле доктор філософії в галузі державного управління, тел.: (063) 951-78-55, e-mail: Scurba_2018@ukr.net, https://orcid.org/ 0000-0001-5391-8884

\title{
ДЕЯКІ ПИТАННЯ ГАРМОНІЗАЦІЇ ЗАКОНОДАВЧОЇ БАЗИ ЄС 3 ПРОТИДІЇ ВІДМИВАННЮ КОШТІВ ТА ФІНАНСУВАННЮ ТЕРОРИЗМУ
}

Анотація. Відмічено, що боротьба з відмиванням коштів та фінансуванням тероризму стала найважливішою проблемою сучасного суспільства. Розвиток науки, технологій, технічних засобів, крім величезного впливу на процеси розвитку людства, виявив i негативні тенденції. Всі ці фактори стали використовуватися у злочинній діяльності. Поруч з цим виникла серйозна загроза розвитку суспільства. При здійсненні злочинів використовуються наукові знання, новітні технічні засоби. Змінилася структура злочинів і їх підготовка. Зазначено, що успішне кримінальне провадження 3 міжнародних справ вимагає єдиних Європейських правил. За відсутності такого повністю узгодженого європейського кримінального права стаття 82 TFEU встановлює мінімальні стандарти для взаємного визнання судових рішень і позасудових рішень між окремими державами-членами в кримінальних справах. Таким чином, стаття $82 \epsilon$ невід'ємною частиною AFSJ і сприяє забезпеченню безпеки і справедливості. Стаття 82 (1) TFEU регулює співробітництво судових органів в рамках $\mathrm{CC}$ на основі взаємного визнання судових рішень, яке включає гармонізацію правових положень держав-членів в областях, згаданих у статтях 82 (1) (2) і 83 TFEU.

Обгрунтовано, що на практиці недостатне визначення РЕР відповідно до AMLD 4 і одночасне розширення його охоплення до членів сім'ї та інших пов'язаних сторін означає, що багато банків, побоюючись можливих ризиків, колективно відмовляються від відкриття рахунків, що призводить до необгрунтованої дискримінації. Незважаючи на те, що AMLD 4 прямо заявляє, 
що статус РЕР не повинен призводити до дискримінації, насправді це так. Залишається неясним, які причини виправдовують розширені перевірки членів сім'ї та пов'язаних з ними осіб в контексті РЕР.

Актуалізовано думку по те, що інтеграція СТF і включення запобігання ухиленню від сплати податків в рамках AML в $\mathrm{CC}$ мають на увазі об'єднання на різних рівнях абсолютно різних явищ, що робить всю систему неефективною $\mathrm{i}$ юридично сумнівною.

Ключові слова: гармонізація законодавчої бази $\mathrm{EC}$, протидія відмиванню коштів, фінансування тероризму, податкові правопорушення, віртуальна валюта.

Fedorenko Vladislav Leonidovich Doctor of Law, Professor, Director of the Research Center for Forensic Examination on Intellectual Property of the Ministry of Justice of Ukraine, Honored Lawyer of Ukraine, 26, L. Ukrainka Boulevard, office 501, Kyiv, 01133, tel.: (044) 592-14-01, e-mail: fedorenko900@gmail.com, https://orcid.org/ 0000-0001-5902-1226

Zhukova Iryna Vitaliivna Candidate of Sciences in Public Administration, Docent, Vice-Rector for Research Work of the Private Higher Educational Institution University of New Technologies, 5A Metrobudivska St., Kyiv, 03067, tel.: (063) 951-78-55, e-mail: irina_pravo@ukr.net, https://orcid.org/0000-0003-4927-0610

Schurba Michele Doctor of Philosophy in Public Administration, tel.: (063) 951-78-55, e-mail: Scurba_2018@ukr.net, https://orcid.org/ 0000-0001-5391-8884

\section{SOME ISSUES OF HARMONIZATION OF THE EU LEGAL FRAMEWORK FOR COMBATING MONEY LAUNDERING AND TERRORIST FINANCING}

Abstract. It is noted that the fight against money laundering and terrorist financing has become the most important problem of modern society. The development of science, technology, technical means, in addition to the huge impact on the development of mankind, has revealed negative trends. All these factors began to be used in criminal activity. Along with this, there was a serious threat to the development of society. When committing crimes, scientific knowledge and the latest technical means are used. The structure of crimes and their preparation has changed. It is noted that successful criminal proceedings in international affairs require uniform European rules. In the absence of such a fully harmonized European criminal law, Article 82 TFEU sets minimum standards for the mutual recognition of judgments and extrajudicial decisions between individual Member States in criminal matters. Thus, Article 82 is an integral part of the AFSJ and promotes security and justice. Article 82 (1) TFEU governs judicial cooperation within the EU on the basis of mutual recognition of judgments, which includes the harmonization of the legal provisions of 
the Member States in the areas referred to in Articles 82 (1) (2) and 83 TFEU.

It is justified that in practice the insufficient definition of PEP under AMLD 4 and the simultaneous extension of its coverage to family members and other related parties means that many banks, fearing possible risks, collectively refuse to open accounts, leading to unjustified discrimination. Although AMLD 4 explicitly states that PEP status should not lead to discrimination, this is in fact the case. It remains unclear what reasons justify the expanded inspections of family members and related persons in the context of PEP.

The opinion that the integration of CTF and the inclusion of tax evasion in the framework of AML in the EU implies the association of completely different phenomena at different levels, which makes the whole system inefficient and legally questionable.

Keywords: harmonization of EU legislation, anti-money laundering, terrorist financing, tax offenses, virtual currency.

Постановка проблеми. Боротьба з відмиванням коштів та фінансуванням тероризму стала найважливішим завданням як кожної окремо взятої держави світу, так і міжнародної спільноти в цілому. Адже поглиблення «тінізації» коштів не тільки послабляє національну безпеку і оборону держав та у протиправний спосіб обмежує податкову базу, а й сприяє виведенню 3 державних бюджетів коштів, які можуть витрачатися в злочинних цілях, зокрема для фінансування тероризму, корупції, наркобізнесу, торгівлі людьми тощо.

Глобалізація, як режим вільного переміщення робочої сили, капіталів i товарів, стрімкий розвиток і трансферт технологій, діджиталізація суспільного та державного життя та інші новації XXI ст. сприяли не лише цивілізаційному розвиткові людства, а й посиленню національної та транснаціональної злочинності. Сучасні злочини у сфері відмивання коштів і фінансування тероризму стали добре організованими i високотехнологічними, що унеможливлює їх швидку і ефективну профілактику та припинення. Змінився суб'єктно-об'єктний склад відповідних злочинів, а також алгоритми їх скоєнння.

Зокрема, перед Україною, як і перед багатьма іншими державами світу, в останні роки постала «проблема криптовалют». 3 одного боку, ці віртуальні активи сприяють диверсифікації інвестиційного інструментарію, створюють альтернативу цінним паперам, банківським металам, депозитним вкладам тощо, а 3 іншого - невизначеність правового статусу крипотвалют і безконтрольність операцій із ними, робить віртуальні активи привабливим інструментарієм відмивання коштів, отриманих незаконним шляхом. Реагуючи на ці виклики, Верховна Рада України прийняла 8 вересня 2021 року в другому читанні та в цілому Закон України «Про віртуальні активи», які було визначено, як систему даних в електронній формі, що має свою вартість та існує в системі обігу віртуальних активів. При цьому, віртуальний актив, за згаданим Законом, може бути як самостійним, виокремленим об'єктом цивільного обороту, так i 
посвідчувати майнові або немайнові права. Зокрема, посвідчувати права вимоги на інші об'єкти цивільних прав тощо.

На сьогодні Закон України «Про віртуальні активи» знаходиться на підписі у глави держави. Але, легалізація криптовалюти і встановлення чітких правил i законних обмежень щодо іiі використання на національному рівні вимагає відповідних кроків на міжнародному рівні. Без унормування статусу і режиму використання віртуальних активів на міжнародному рівні, цей фінансовоінвестиційний інструментарії й надалі знаходитиметься в центрі уваги транснаціональної злочинності. Одночасно з цим, наведений приклад є нагодою дослідити окремі проблемні питання гармонізації чинного законодавства України iз законодавством СС у сфері відмивання коштів і фінансування тероризму, у тому числі й у контексті міжнародного транскордонного співробітництва.

Аналіз останніх досліджень і публікацій. Варто відмітити важливу роль науковців, які досліджували дану проблематику, а саме: Л. Аркуші, Л. БагрійШахматова, О. Бандурки, Ю. Битяка, М. Бурбика, О. Бусола, О. Винника, I. Голосніченка, В. Грохольського, Ю. Дем'янчука, I. Зозулі, А. Куліша, М. Логвиненка, М. Мельника, О. Музичука, Н. Міняйла, Є. Невмержицького, О. Шевченко та ін. Разом із тим, проблематика, винесена в заголовок цієї статті, зберігає свою актуальність, в силу динамічності досліджуваних процесів, i на сьогодні.

Мета статті. Метою цього дослідження $є$ подальше формування науковометодологічних основ правотворчої та правозастосовної діяльності в Україні в сфері протидії відмиванню коштів та фінансуванню тероризму та гармонізації чинного законодавства України із законодавством СС у сфері відмивання коштів і фінансування тероризму.

Виклад основного матеріалу. Міжнародне транскордонне співробітництво було створено до підписання Лісабонського договору через Конвенцію ООН проти транснаціональної організованої злочинності (Палермська конвенція) 2000 року, яка була включена в національне законодавство Італії в якості Закону 146/2006 [1]. Проте, необхідність вирішення проблем, що виникають з юрисдикцій, що суперечать одна одній в переслідуванні транснаціональних злочинів на рівні $€ C$, залишилась [2]. Рамкове рішення Ради 2008/841 / JНА [3] про боротьбу 3 організованою злочинністю стало важливим кроком у створенні європейського підходу до організованої злочинності, оскільки воно дало визначення структурованої асоціації як відправну точку для організованої злочинності і звід положень про покарання за участь в злочинних організаціях на рівні СС.

Це рамкове рішення дозволило країнам-членам налагодити співпрацю в переслідуванні організованої злочинності, але не змогло домогтися гармонізації законодавства, оскільки воно не забезпечило інституціоналізованої i систематичної співпраці між усіма державами-членами. Лісабонський договір визнав, що успіхи в боротьбі з транснаціональною злочинністю як всередині ЄС, 
так і на міжнародному рівні вимагають усунення дублюючих юрисдикцій i налагодження ефективного транскордонного співробітництва. Це може бути досягнуто за рахунок набагато більш екстенсивної гармонізації європейського кримінального права, що також було підкреслено в Рамковій рішення Ради 2009/948 / JHA про запобігання та врегулювання конфліктів юрисдикції в кримінальному судочинстві.

Успішне кримінальне провадження 3 міжнародних справ вимагає єдиних Європейських правил. За відсутності такого повністю узгодженого європейського кримінального права стаття 82 TFEU встановлює мінімальні стандарти для взаємного визнання судових рішень і позасудових рішень між окремими державами-членами в кримінальних справах. Таким чином, стаття $82 \epsilon$ невід'ємною частиною AFSJ i сприяє забезпеченню безпеки і справедливості. Стаття 82 (1) TFEU регулює співробітництво судових органів в рамках $С С$ на основі взаємного визнання судових рішень, яке включає гармонізацію правових положень держав-членів в областях, згаданих у статтях 82 (1) (2) і 83 TFEU. У зв'язку зі Статтею 83 (1) TFEU, EC тепер має право визначати мінімальні правила для серйозних транскордонних злочинів 3 точки зору кримінальних злочинів $\mathrm{i}$ покарання, включаючи тероризм, торгівлю людьми і наркотиками, відмивання грошей, корупцію i організовану злочинність. На практиці транскордонне кримінальне переслідування в основному відповідає рамковим рішенням, укладеними на підставі статті 34 TEU.

У боротьбі з фінансовими злочинами вони включають, зокрема, Директиву 2015/849 і Директиву 2014/62 / ЕС [4]. В областях, необхідних для ефективного застосування європейської політики, таких як запобігання зловживань фінансовими інститутами на ринку, як викладено в Директиві 2014/57, стаття 83 (2) TFEU передбачає європейську гармонізацію. Стаття 82 TFEU встановлює взаємне визнання судових рішень та інших адміністративних рішень, щоб уникнути конфліктів юрисдикції. [5]

Створення Євроюсту, як європейського центру 3 координації судової співпраці між національними правоохоронними органами, має важливе значення в боротьбі 3 організованою злочинністю i відмиванням грошей. Створення європейського поліцейського підрозділу Свропол в якості незалежної міжнародної організації в 2009 р. стало ще одним кроком на шляху до боротьби 3 транскордонною злочинністю. Першим завданням Європолу $є$ сприяння обміну інформацією між національними поліцейськими органами, збір і аналіз інформації скоординованим чином і передача їі поліцейським органам держав-членів.

Обмін інформацією, особливо в області тероризму і відмивання грошей, має центральне значення для успішного контролю за злочинністю. Згідно зі Статтею 86 (1) (1), TFEU дозволяє створення Європейської прокуратури через Постанову Ради ЄС. Одне із завдань європейського прокурора полягає в судовому веденні кримінальних справ, які у фінансовому відношенні обмежують 
EC відповідно до статті 325 TFEU i порушення справ по серйозним транскордонним злочинам

Однак обвинувальний акт або звинувачення повинні бути пред'явлені відповідним національним судом юрисдикції. В цілому, неясно, чи можна очікувати поліпшення в переслідуванні серйозних правопорушень на рівні ЄС до тих пір, поки не будуть вирішені деякі основні питання, такі як фундаментальне питання про те, як проваджувати кримінальне судочинство в державах-членах без повного європейського юридичного узгодження або питання про те, які засоби правового захисту мають підзахисні, коли вони постають перед європейським державним прокурором.

Тому, Україні та іншим демократичним державам світу вкрай важливо мати демократичні механізми стримування і балансу в Європейській прокуратурі i Європолі для забезпечення справедливості будь-якого кримінального судочинства.

AMLD 4 призначена для запобігання зловживання фінансовою системою неблагонадійними учасниками шляхом створення прозорості за допомогою створення центральних регістрів даних в кожній державі-члені $\epsilon С$, які $\epsilon$ загальнодоступними i дозволяють ідентифікувати кінцевих бенефіціарів власників. Крім того, було встановлено підхід, заснований на оцінці ризику для належної обачності клієнтів. Хоча AMLD 4 надає підрозділу фінансової розвідки (ПФР) значно більшу автономію в оцінці та доступі до даних, пов'язаних з ML i $\mathrm{TF}$, а також податковими правопорушеннями, Комісія ЄC вказала на існуючі прогалини, які необхідно було закрити в третіх країнах з високим рівнем ризику, платформах обміну віртуальною валютою і в передплачених інструментах; крім того, Комісія закликала до подальшого вдосконалення центральних регістрів даних для електронних платежів, включаючи більш широкий доступ до інформації і обмін між ПФР, який закріплений в остаточному Проекті СОМ (2016) 450.

На відміну від AMLD 3, розділ III AMLD 4 вимагає від держав-членів забезпечити, щоб інформація про бенефіціарну власність та бенефіціарні інтереси, пов'язані 3 компаніями та іншими юридичними особами, які перебувають у відповідній державі-члені, була доступна в центральному реєстрі, який є загальнодоступним відповідно до статті 30 (3) і (4) четвертої AMLD. Kрім того, держави-члени повинні забезпечити, щоб компетентні органи і ПФР, виконують належну перевірку клієнтів, мали необмежений доступ до цього реєстру весь час. Четверта AMLD розширює ці зобов'язання щодо розкриття інформації ще раз відповідно до статті 31, зобов'язуючи довірених осіб будьякого юридично можливого типу довіри у відповідній державі-члені дотримуватися цієї вимоги прозорості. Подальша зміна в порівнянні з AMLD 3 полягає в тому, що для всіх осіб і компаній, охоплених AMLD 4, потрібні ризикорієнтований підхід і документація. Крім того, потрібна оцінка ризику PEPs, в 
той час як група, яка буде вважатися PEPs, була значно розширена.

На практиці недостатнє визначення PEP відповідно до AMLD 4 і одночасне розширення його охоплення до членів сім'ї та інших пов'язаних сторін означає, що багато банків, побоюючись можливих ризиків, колективно відмовляються від відкриття рахунків, що призводить до необгрунтованої дискримінації. Незважаючи на те, що AMLD 4 прямо заявляє, що статус PEP не повинен призводити до дискримінації, насправді це так. Залишається неясним, які причини виправдовують розширені перевірки членів сім'ї та пов'язаних з ними осіб в контексті PЕР [6]. Оскільки де-факто перед кожним банком залишено рішення про те, наскільки далеко заходить ця інспекція і як вона виглядає, AMLD 4 створює навіть більше невизначеності для банків і їх клієнтів.

3 одного боку, вимоги належної обачності відповідно до AMLD 4 є більш жорсткими при наявності ризиків; 3 іншого боку, вимоги можуть бути значно спрощені, коли демонструються більш низькі ризики. Стаття 288 TFEU надає країнам-членам можливість реалізувати AMLD 4 на національному рівні. Наприклад, у Великій Британії для реалізації Директиви був потрібен дворічний перехідний етап, вона набула чинності 26 червня 2017 року.

Четверта AMLD включає Конвенцію ООН 1988 року проти незаконного обігу наркотичних засобів і психотропних речовин в статті 3 (4) (b) i Рекомендації ФАТФ 2012 року в четвертої редакції, включаючи також Конвенцію ООН проти транснаціональної організованої злочинності 2000 року (Палермська конвенція) з обов'язковою дією. В кінцевому рахунку, AMLD 4 прагне виявити порушення ML та TF і ухилення від сплати податків шляхом максимального обміну інформацією на європейському рівні, що де-факто означає скорочення захисту персональних даних, що ставить під загрозу принципи верховенства закону в кримінальному праві.

Ця правозастосовна практика частково утруднена Європейським судом (ЕСЈ), про що свідчать рішення Digital Rights Ireland and Seitlinger and Others [2014] i Schrems v Data Protection Commissioner [2015].

Незважаючи на те, що закон США дозволяє американській розвідці мати доступ до особистих даних громадян $\mathrm{CC}$, Свропейський суд визнав цю практику неприйнятною в ЄС, оскільки не забезпечується адекватний захист конфіденційності, що призводить до явного порушення законодавства ЄС. Відповідно, порушення статей 7, 8 і 11 Статуту основних прав Свропейського Союзу (Хартія) призвело до того, що ЕСJ не тільки класифікував передачу персональних даних владі США як неприпустиму, а й анулював Директиву про захист даних 95/46. Причина анулювання полягала в тому, що стаття 25 Директиви 95/46 щодо Рішення Комісії про адекватність 2000/520 допускала занадто далекоглядний екстериторіальний ефект законодавства США і відповідну компетенцію влади США щодо контролю за даними громадян СС. В кінцевому підсумку Європейський суд підтвердив, що це законодавство суперечить Статуту щодо захисту даних і приватного життя. 
Крім підходу, заснованого на оцінці ризику, AMLD 4 також зосередила увагу на оцінці національних ризиків. У зв'язку з цим Базельський комітет 3 банківського нагляду, аналогічний AMLD 4, прийняв Рекомендації ФАТФ від 2012 року в своїх інструкціях за січень 2014 «Оцінка управління ризиками щодо відмивання грошей і фінансування тероризму».

Тут оцінки ризиків описуються як основний обов'язок кредитних i фінансових установ, i вказані три напрямки захисту від відмивання грошей: Перша лінія оборони - це співробітники фронт-офісу, які знаходяться в безпосередньому контакті 3 клієнтом; вони відповідають за ідентифікацію клієнта, за доступ і моніторинг бізнес-ризиків, а також за реалізацію відповідних політик і процедур AML / CTF. Друга лінія оборони - це вище керівництво, яке відповідає за постійний моніторинг і виконання вимог AML / CTF і є контактною особою для пов'язаних з AML / CTF питань від внутрішніх і зовнішніх органів i управління фінансової розвідки (FIU). Третьою лінією захисту від відмивання грошей $є$ внутрішній аудит, який забезпечує незалежну оцінку ефективності управління ризиками та контролю за політикою і процедурами AML / CTF. У той же час взаємозв'язок рекомендацій Базельського комітету, AMLD 4 i iнші нормативні технічні стандарти, встановлені Європейськими наглядовими органами, створюють все більш тонку мережу контролю за фінансовими установами.

Ця мережа стає все масштабнішою, оскільки Європол стає більш тісно залученим в боротьбу 3 фінансовими злочинами $і$ центральним вузлом інформації, де відбувається обмін і оцінка даних на безпрецедентних рівнях. Європол активно брав участь в пропозиціях, що містяться в угоді між СС і США про Програму відстеження тероризму (ТFTР). Боротьба з фінансовими злочинами тепер розширюється пропозиціями про майбутню AMLD 4 з внесенням поправок або п’яту AMLD, Особливо слід відзначити, що вимоги до належної обачності щодо прозорості бенефіціарної власності повинні стати більш жорсткими. Зокрема, справа про «Панамські документи» сприяла більшій концентрації уваги на попередженні податкових ухилень і контролі за рухом анонімних коштів. На цьому тлі пропозиція Ради СС СОМ / 2016/450, в якій передбачається закрити прогалини в області ML i TF, є досить проблематично. через те, що мета закриття прогалин змішується з метою створення більшої прозорості фінансових операцій щодо офшорних юрисдикцій з метою запобігання ухиленню від сплати податків.

Висновки. В кінцевому рахунку, інтеграція СТF і включення запобігання ухиленню від сплати податків в рамках AML в ЄC мають на увазі об'єднання на різних рівнях абсолютно різних явищ, що робить всю систему неефективною $\mathrm{i}$ юридично сумнівною. В кінцевому рахунку, інтеграція СТF i включення запобігання ухиленню від сплати податків в рамки AML в $\mathrm{CC}$ мають на увазі об'єднання на різних рівнях абсолютно різних явищ, що робить всю систему неефективною і юридично сумнівною. 


\section{Лimepamypa:}

1. Open Society Justice Initiative, 'Corruption and its Consequences in Equadorial Guinea. A Briefing Paper' (March 2010)

2. L Pagotto and APB Teixeira, 'The Brazilian Anti-Corruption Policy in Motion' (2016) Business Law International 17(2) 103-125

3. J Park, 'Corruption, Soundness of the Banking Sector, and Economic Growth: A CrossCountry Study' (2012) Journal of International Money and Finance 31(5) 907-929

4. S Preller, 'Comparing AML Legislation to the UK, Switzerland and Germany' (2008) Journal of Money Laundering Control 11(3) 234-250

5. R Quedenfeld, 'Grundlagen der Geldwдschebekдmpfung' in R Quedenfeld (eds), Handbuch. Bekdmpfung der Geldwdsche und Wirtschaftskriminalitdt (4th edn, ESV 2017)

6. Reuters Staff, 'Standard \& Poor's Downgrades Petrobras after Brazil Sovereign Cut' (Reuters, 18 February 2016) <https://www.reuters.com/article/us-petrobras-rating/standard-poors-downgradespetrobras-after-brazil-sovereign-cut-idUSKCN0VR1I6> accessed 4 October 2017

\section{References:}

1. Open Society Justice Initiative, 'Corruption and its Consequences in Equadorial Guinea. A Briefing Paper' (March 2010)

2. L Pagotto and APB Teixeira, 'The Brazilian Anti-Corruption Policy in Motion' (2016) Business Law International 17(2) 103-125

3. J Park, 'Corruption, Soundness of the Banking Sector, and Economic Growth: A CrossCountry Study’ (2012) Journal of International Money and Finance 31(5) 907-929

4. S Preller, 'Comparing AML Legislation to the UK, Switzerland and Germany' (2008) Journal of Money Laundering Control 11(3) 234-250

5. R Quedenfeld, 'Grundlagen der Geldwдschebekдmpfung' in R Quedenfeld (eds), Handbuch. Bekdmpfung der Geldwdsche und Wirtschaftskriminalitdt (4th edn, ESV 2017)

6. Reuters Staff, 'Standard \& Poor's Downgrades Petrobras after Brazil Sovereign Cut' (Reuters, 18 February 2016) <https://www.reuters.com/article/us-petrobras-rating/standard-poors-downgradespetrobras-after-brazil-sovereign-cut-idUSKCNOVR1I6> accessed 4 October 2017 